\title{
Diplocirrus nicolaji (Annelida: Flabelligeridae) from Japan, detailed morphological observation and DNA barcoding
}

Naoto Jimi ${ }^{1} 2^{*}$, Masaatsu Tanaka $^{3}$ and Yoshihiro Fujiwara ${ }^{1,2}$

\begin{abstract}
Diplocirrus nicolaji is a flabelligerid worm originally described from shallow waters of Peter the Great Bay, Sea of Japan. Later, this species was also recorded from Japan, but detailed data were not provided; thus the occurrence of D. nicolaji in Japan needs to be confirmed based upon additional material. The collection of 20 D. nicolaji individuals from four localities along Japanese coasts (the Sea of Japan and western Pacific Ocean), allowed us to provide detailed morphological observations using stereoscopic and scanning electron microscopy. Partial cytochrome c oxidase subunit I sequences were obtained for phylogenetic analysis. Although the morphological analysis detected a few variations in palp length and body colour in ethanol among the local populations, the phylogenetic analysis confirmed their conspecificity with little genetic divergence. This is the first report of $D$. nicolaji from the western Pacific Ocean and extends its distribution southward.
\end{abstract}

Keywords: Polychaete, Diplocirrus nicolaji, DNA barcoding, Japanese waters

\section{Background}

The annelid family Flabelligeridae is generally recognized as a sedentary group living within soft sediments or hard substrates (Rouse and Pleijel 2001); however, recent morphological and molecular phylogenetic studies show that the family also contains some holopelagic species (Burnette et al. 2005; Osborn and Rouse 2008; Salazar-Vallejo et al. 2008). In Japan, the records of flabelligerids are relatively few and scattered. To our knowledge, the following 13 species of Flabelligeridae have so far been recorded from Japanese waters: Brada inhabilis, Br. mammillata, Br. ochotensis, Br. villosa, Buskiella vitjasi, Daylithos parmatus, Flabelligera affinis, Pherusa moorei, Ph. nipponica, Ph. papillata, Piromis suni, Semiodera nishii, and Stylarioides longisetosa (Imajima 1964, 2006, 2009 and Hartman 1964;

\footnotetext{
* Correspondence: beniimo7010@gmail.com

${ }^{1}$ Graduate School of Biosphere Science, Hiroshima University,

Higashi-Hiroshima 739-8528, Japan

${ }^{2}$ Department of Marine Biodiversity Research, Japan Agency for Marine-Earth

Science and Technology, Yokosuka 237-0061, Japan

Full list of author information is available at the end of the article
}

Uchida 1992; Jirkov 2001; Salazar-Vallejo 2011a, b, 2012, 2014; Miura 2014).

The flabelligerid genus Diplocirrus Haase, 1915 is characterized by having a club-shaped body, two types of retractable branchiae, and multiarticulate chaetae in both parapodia rami. After the comprehensive taxonomic revision by Salazar-Vallejo and Buzhinskaja (2011), the two monotypic genera Bradiella Rullier, 1965 and Diversibranchius Buzhinskaja, 1994 were synonymized with Diplocirrus; consequently, the genus currently consists of 13 species, of which three are still undescribed (Salazar-Vallejo and Buzhinskaja 2011), that live on soft bottoms in sublittoral depths worldwide.

Diplocirrus nicolaji (originally combined with the newly established genus Diversibranchius) was described based on specimens collected from shallow waters of Peter the Great Bay, the Sea of Japan, Russia (Buzhinskaja 1994). Thereafter, an unidentified "Flabelligeridae from Japan" was illustrated in Rouse and Pleijel (2001), which was later identified as D. nicolaji by Salazar-Vallejo and Buzhinskaja 
(2011) on the basis of their reexamination of the photographed material of Rouse and Pleijel (2001) (Salazar-Vallejo, personal communication). However, neither Rouse and Pleijel (2001) nor Salazar-Vallejo and Buzhinskaja (2011) provided the precise collection sites of their material; no other record of this species has been reported from Japanese waters. Thus, the distribution of $D$. nicolaji in Japan needs to be clarified.

During the course of a survey of Japanese polychaete fauna by the first and second authors, some flabelligerid worms were collected from four localities of Japan (Oshoro, Tateyama, Misaki, and Komatsubara). After morphological observation, we identified these flabelligerids as D. nicolaji. In this paper, we report the morphology of these Japanese D. nicolaji specimens including observations of the detailed structure of the taxonomic characters using a scanning electron microscope (SEM). In addition, we also obtained partial mitochondrial cytochrome $c$ oxidase subunit I (COXI) sequences for conducting phylogenetic analysis and for contributing to DNA barcoding of Flabelligeridae.

\section{Methods}

\section{Materials}

Worms were collected in Oshoro, Hokkaido $\left(43^{\circ} 12^{\prime} 33^{\prime \prime} \mathrm{N}\right.$, $140^{\circ} 51^{\prime} 30^{\prime \prime E}$ ) (Fig. 1a) and Komatsubara beach, Hiroshima prefecture, Seto Inland Sea $\left(34^{\circ} 16^{\prime} 42^{\prime \prime N}, 132^{\circ} 47^{\prime} 16^{\prime \prime} \mathrm{E}\right)$ (Fig. 1b) by hand from shallow waters (2-m depth), and in Tateyama Bay, Chiba prefecture $\left(34^{\circ} 59^{\prime} 04.7^{\prime \prime} \mathrm{N}, 139^{\circ}\right.$ 48'57.4"E) (Fig. 1c) at a depth of 4-10 m and Misaki, Kanagawa prefecture, Sagami Bay $\left(35^{\circ} 09^{\prime} 30^{\prime \prime} \mathrm{N}, 139^{\circ}\right.$ $36^{\prime} 46^{\prime \prime E}$ ) (Fig. 1d) at a depth of $4 \mathrm{~m}$ by a dredge. All the specimens were first anesthetized with menthol and then fixed and preserved in $70 \%$ ethanol. The anesthesia durations were different among each specimen.

\section{Morphological observations}

Preserved specimens were observed with an MZ $16 \mathrm{~F}$ stereoscopic microscope (Leica, Germany), two of which were treated for SEM. The specimens for SEM observations were washed in filtered artificial seawater and postfixed with $2 \% \mathrm{OsO}_{4} /$ artifical seawater for $2 \mathrm{~h}$. After six washes with deionized water (DW), the specimens were incubated with $0.2 \%$ aqueous tannic acid ( $\mathrm{pH}$ 6.8) for $30 \mathrm{~min}$ for conductive staining. The specimens were washed again

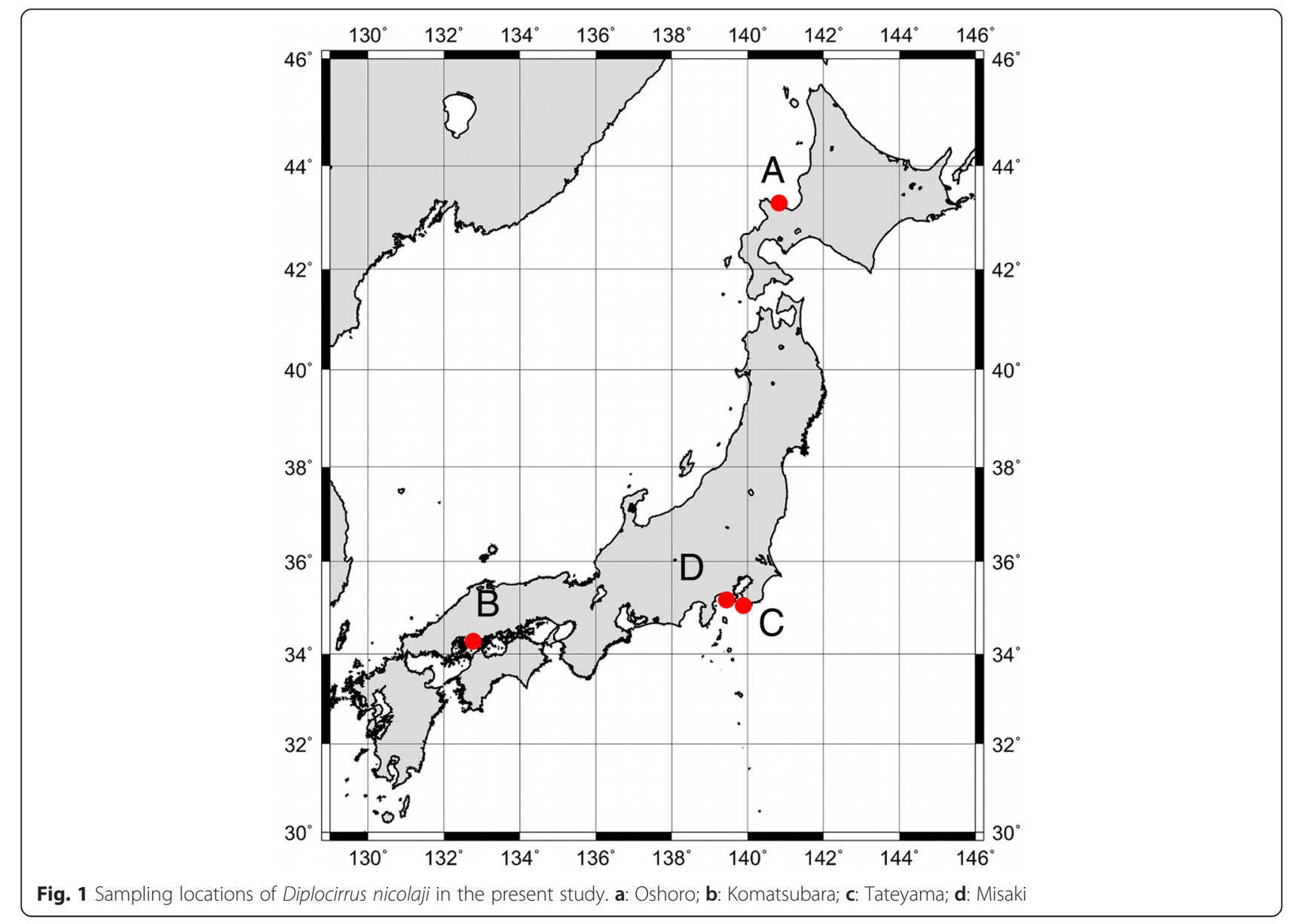


with DW, treated with $1 \% \mathrm{OsO}_{4} / \mathrm{DW}$ for $30 \mathrm{~min}$, and then washed with DW. The specimens were dehydrated in a graded ethanol series, dried in a JCPD-5 (JEOL, Japan) critical point dryer using liquid $\mathrm{CO}_{2}$, and coated with osmium in a POC-03 (Meiwafosis, Japan) for $5 \mathrm{~s}$. SEM observations were conducted using a JSM-6700 F instrument (JEOL, Japan).

\section{DNA extraction, amplification, sequencing, and phylogenetic analysis}

The total genomic DNA was extracted from eight specimens using a DNeasy Blood \& Tissue Kit (Qiagen, USA) following the manufacturer's protocol. Partial COXI (ca. 650-bp) sequences were amplified by the polymerase chain reaction (PCR) with the primers polyLCO (5' -GAYTATWTTCAACAAATCATAAAGATATTGG-3') and polyHCO (5'-TAMACTTCWGGGTGACCAAAR AATCA-3') (Carr et al. 2011). The reaction mixture consisting of $0.25 \mu \mathrm{l}$ TaKaRa Ex Taq (Takara, Japan), $5 \mu \mathrm{l}$ of $10 \times$ Ex Taq Buffer (Takara), $4.0 \mu \mathrm{l}$ dNTP mixture (Takara), $5 \mu \mathrm{l}$ of each primer pair $(10 \mu \mathrm{M})$, $0.75 \mu \mathrm{l}$ of extracted DNA, and $35 \mu \mathrm{l}$ of distilled water was prepared. The PCR protocol consisted of an initial denaturation step at $94{ }^{\circ} \mathrm{C}$ for $1 \mathrm{~min}$, followed by 35 cycles of 30 -s denaturation at $94{ }^{\circ} \mathrm{C}$, 60 -s annealing at $55^{\circ} \mathrm{C}$, and 1 -min extension at $72^{\circ}$ $\mathrm{C}$, with a final extension at $72{ }^{\circ} \mathrm{C}$ for $10 \mathrm{~min}$. To confirm successful amplifications, PCR products were visualized using 1.2 \% Agarose S (Nippon Gene, Japan) gel electrophoresis. Successful PCR products were purified by Wizard SV Gel and PCR Clean-Up System (Promega, USA) following the manufacturer's protocol. The DNA sequencing reaction of the PCR products was performed using a BigDye Terminator v3.1 Cycle Sequencing Kit (Applied Biosystems, USA). Direct sequencing was performed using a 3130xl Genetic Analyzer (Applied Biosystems). Sequencing reactions were conducted using the 1$\mu \mathrm{M}$ primers applied for the PCR amplifications. The newly obtained sequences were deposited in DDBJ/EMBL/Gen Bank (accession nos. LC056917-LC056924).

Additional Flabelligeridae and Acrocirridae COXI sequences were also obtained from DDBJ/EMBL/Gen Bank (Table 1). All sequences were aligned using Mesquite version 2.75 (Maddison and Maddison 2011), taking each codon position into account. A phylogenetic tree was constructed using the maximum likelihood (ML) method. The ML tree was obtained using the partitioned method (partitions per each codon position) as implemented in RAxML-VIHPC (Stamatakis 2006) and its graphical interface raxmlGUI version 1.3 (Silvestro and Michalak 2012). As recommended in the RAxML-VI-HPC manual (Stamatakis 2006), the general time-reversible model with sites following a discrete gamma distribution
$(G T R+\Gamma)$ (Tavaré 1986; Yang 1993) for each partition was used without incorporating a proportion of invariant sites. Rapid bootstrap analysis was conducted with 1,000 replicates ( $\mathrm{f}$ a option). Pairwise genetic distances $[ \pm$ standard deviation $(\mathrm{SD})]$ were calculated on the basis of the COXI sequence using the uncorrected $p$-distance and Kimura's twoparameter (K2P) model (Kimura, 1980), as implemented in MEGA6.06 (Tamura et al. 2013).

\section{Results}

\section{SYSTEMATICS}

Family Flabelligeridae de Saint-Joseph, 1894

Genus Diplocirrus Haase, 1915

(New Japanese name: Konbouhabouki-zoku)

Diplocirrus nicolaji (Buzhinskaja, 1994)

(New Japanese name: Bouzu-habouki)

(Figs. 2, 3)

Diversibranchius nicolaji Buzhinskaya, 1994: 231, figures 2-7; Darbyshire and Mackie 2009: 97, Table 1.

Flabelligeridae from Japan: Rouse and Pleijel 2001, plate 11 , figure $\mathrm{f}$.

Diplocirrus nicolaji: Salazar-Vallejo and Buzhinskaja 2011, 31-33 figure 9.

\section{Material examined}

Oshoro: NSMT-Pol-113032, One of unknown sex, Body length $36.2 \mathrm{~mm}$, Body width $1.9 \mathrm{~mm}, 49$ chaetigers, 20 October 2014, coll. N. Jimi, 2 m depth, gravelly sand.

Tateyama: NSMT-Pol-113033, One of unknown sex (anterior fragment), Body length $16.0 \mathrm{~mm}$, Body width $3.0 \mathrm{~mm}, 19$ chaetigers, 6 March 2015, coll. M. Tanaka, 4-10 m depth, sand.

Misaki: NSMT-Pol-113034, 113036, 12 of unknown sex (one complete specimen and 11 anterior fragments), Body length $8.0-18.6 \mathrm{~mm}$, Body width $1.8 \mathrm{~mm}, 29$ chaetigers, 16 October 2014, coll. N. Jimi, $4 \mathrm{~m}$ depth, sand.

Komatsubara: NSMT-Pol-113035, Six of unknown sex (two complete specimens and four anterior fragments), Body length 17.0-26.2 mm, Body width $1.2-1.7 \mathrm{~mm}$, 31-51 chaetigers, 2 September 2014, coll. N. Jimi, $2 \mathrm{~m}$ depth, sandy mud.

\section{Description}

Body length $8.0-36.2 \mathrm{~mm}$ and width $1.2-1.9 \mathrm{~mm}$, chaetigers 29-51, and orange yellow in colour. Anterior and last few segments slightly swollen. Cephalic cage absent (1st chaetiger notochaeta $0.2-$ $0.5 \mathrm{~mm})$. Tunic densely covered by digitate or bowling-pin shaped papillae which arranging as 1017 rows per segment (Fig. 2a). Cephalic hood white colour and thinly covered by papillae. Eyes absent (Fig. 3a). One pair of palps, which $0.8-8.3 \mathrm{~mm}$ long, grooved. Lobes reduced and rounded. Two types of 
Table 1 List of flabelligerid and acrocirrid species included in the phylogenetic analysis, together with accession numbers in DDBJ/ EMBL/GenBank

\begin{tabular}{|c|c|c|c|}
\hline Taxon_\# & Accession number & Collection site & Reference \\
\hline \multicolumn{4}{|l|}{ Flabelligeridae } \\
\hline Brada villosa_1 & HM473328 & British Columbia, Sechelt, Possie Island, Canada & Carr et al. (2011) \\
\hline Brada villosa_2 & HQ024268 & Nunavut, Resolute, Resolute Bay, Canada & do. \\
\hline Brada villosa_3 & HQ024269 & do. & do. \\
\hline Brada villosa_4 & HQ024270 & do. & do. \\
\hline Brada villosa_5 & HQ024271 & do. & do. \\
\hline Brada sp._1 & HQ023866 & Newfoundland and Labrador, Saglek Fjord, Canada & do. \\
\hline Brada sp._2 & HQ024267 & Nunavut, Resolute, Resolute Bay, Canada & do. \\
\hline Brada sp._3 & HQ326970 & Central California, USA & Osborn and Rouse (2011) \\
\hline Coppingeria cf. longisetosus ${ }^{1}$ & HQ326971 & Spencer Gulf, South Australia & do. \\
\hline Diplocirrus longisetosus_1 & HQ024289 & Nunavut, Resolute, Resolute Bay, Canada & Carr et al. (2011) \\
\hline Diplocirrus longisetosus_2 & HQ024290 & do. & do. \\
\hline Diplocirrus longisetosus_3 & HQ024291 & do. & do. \\
\hline Diplocirrus longisetosus_4 & HQ024292 & do. & do. \\
\hline Diplocirrus longisetosus_5 & HQ024293 & do. & do. \\
\hline Diplocirrus longisetosus_6 & HQ024294 & do. & do. \\
\hline Diplocirrus longisetosus_7 & HQ024295 & do. & do. \\
\hline Diplocirrus longisetosus_8 & HQ024296 & do. & do. \\
\hline Diplocirrus longisetosus_9 & GU672433 & Kandalaksha Bay, Velikaya Salma Strait, Russia, 10 m depth & Hardy et al. (2011) \\
\hline Diplocirrus longisetosus_10 & GU672586 & Kandalaksha Bay, Velikaya Salma Strait, Russia, 35 m depth & do. \\
\hline Diplocirrus nicolaji_1 & LC056917 & Oshoro, Hokkaido, Japan & This study \\
\hline Diplocirrus nicolaji_2 & LC056924 & Tateyama Bay, Chiba Pref., Japan & do. \\
\hline Diplocirrus nicolaji_3 & LC056918 & Misaki, Kanagawa Pref, Japan & do. \\
\hline Diplocirrus nicolaji_4 & LC056919 & do. & do. \\
\hline Diplocirrus nicolaji_5 & LC056920 & do. & do. \\
\hline Diplocirrus nicolaji_6 & LC056921 & Komatsubara Beach, Hiroshima Pref, Japan & do. \\
\hline Diplocirrus nicolaji_7 & LC056922 & do. & do. \\
\hline Diplocirrus nicolaji_8 & LC056923 & do. & do. \\
\hline Flabelliderma ockeri & EU694127 & La Jolla, California, USA & Osborn and Rouse (2008) \\
\hline Flabelligera affinis_1 & HQ024304 & Nunavut, Resolute, Resolute Bay, Canada & Carr et al. (2011) \\
\hline Flabelligera affinis_2 & HQ024305 & Nunavut, Igloolik, Canada & do. \\
\hline Flabelligera affinis_3 & HQ024306 & do. & do. \\
\hline Flabelligera affinis_4 & GU672447 & Kandalaksha Bay, Velikaya Salma Strait, Russia, 10 m depth & Hardy et al. (2011) \\
\hline Flabelligera infundibularis & EU694131 & Astoria, Oregon, USA & Osborn and Rouse (2008) \\
\hline Flabelligera mundata & HQ326969 & South Orkney Islands, Antarctica & Osborn and Rouse (2011) \\
\hline Flabelligera sp._1 & HQ024307 & Nunavut, Resolute, Canada & Carr et al. (2011) \\
\hline Flabelligera sp._2 & HQ024308 & Nunavut, Resolute, Resolute Bay, Canada & do. \\
\hline Flabelligera sp._3 & HQ024309 & do. & do. \\
\hline Pherusa affinis_1 & HQ024180 & New Brunswick, St. Andrews, Indian Point, rocky intertidal, Canada & do. \\
\hline Pherusa affinis_2 & HQ024181 & do. & do. \\
\hline Pherusa affinis_3 & HQ024182 & New Brunswick, St. Andrews, Ministers Island, intertidal, Canada & do. \\
\hline Pherusa affinis_4 & HQ024183 & New Brunswick, St. Andrews, between harbor/DFO, subtidal, Canada & do. \\
\hline Pherusa affinis_5 & HQ024184 & do. & do. \\
\hline
\end{tabular}


Table 1 List of flabelligerid and acrocirrid species included in the phylogenetic analysis, together with accession numbers in DDBJ/ EMBL/GenBank (Continued)

\begin{tabular}{llll}
\hline Pherusa affinis_6 & HQ024185 & New Brunswick, St. Andrews, Bar Road, intertidal mudflat, Canada & do. \\
Flabelligeridae sp. & HM375490 & Canada (58.798 N, 94.15 W) & do. \\
$\begin{array}{l}\text { Pherusa plumosa_1 } \\
\text { Pherusa plumosa_2 }\end{array}$ & HQ023901 & Newfoundland and Labrador, Nachvak Fjord, Canada & do. \\
Acrocirridae (outgroup) & & do. & do. \\
Acrocirrus validus & FJ944525 & Hayama, Sagami Bay, Japan & Osborn et al. (2009) \\
Macrochaeta clavicornis & EU791463 & Vattenholmen, Sweden & Osborn and Rouse (2008) \\
\hline
\end{tabular}

${ }^{1}$ Salazar-Vallejo (2011a) considered the genus Coppingeria Haswell, 1892 as a junior synonym of Stylarioides delle Chiaje, 1831

branchiae present, green colour when alive, but faded to white in ethanol preserved specimens (Fig. 3b, c). Four branchiae in posterior row; 0.5$1.4 \mathrm{~mm}$ long and lamellate. Lamella reaching tips, lamellate surface ciliated, and two sucker-like sockets on lateral side (Fig. 3d). Four branchiae in anterior row; 0.7-1.9 $\mathrm{mm}$ long and lamellate. Lamella reaching to one-third of its branchial length. Branchial surface ciliated (Figs. 2b, 3e). Chaetiger 1 notosetae emerging from dorsal side contrary to following setigers. Chaetigers 3 to 8 or 9 swollen, without clear segmentation of tunic between them. Gonopores orange red, present in chaetigers 2 to 23-48 (Fig. 3f). Parapodia poorly developed. Chaetae emerging directly from body wall. Notochaeta and neurochaeta multiarticulated, 5-7 per bundles (Fig. 2a); 23-26 articles on notochaeta and 9-11 articles on neurochaeta in median chaetigers.

\section{Variation among four localities}

The palp length of the specimen from Oshoro was much longer than that of specimens from the other localities (Fig. 3c). The preserved branchial colour of the specimens from Misaki was often green as in its live state, but the colour of the specimens from other localities are soon faded to white.

\section{Phylogenetic analysis}

The final length of the aligned COXI sequence was $531 \mathrm{bp}$; this contained 230 variable sites, of which 213 sites were parsimony informative. The mean base composition was $28.3 \%$ (A), $20.2 \%$ (C), 16.4\% (G), and $35 \%(\mathrm{~T})$.

The ML tree obtained (Fig. 4) showed that the monophyly of Flabelligeridae was strongly supported (bootstrap $[\mathrm{BS}]$ value $=95 \%$ ); however, the internal relationships within the family were totally unresolved. All the sequences of Diplocirrus nicolaji formed a monophyletic clade with high support value (BS value $=94 \%$ ) and were well discriminated from the remains (Fig. 4). The average genetic divergence of the sequences among $D$. nicolaji was $2.1 \pm 1.6 \%$ in $p$-distance $(2.2 \pm 2 \%$ in K2P). Monophyly of the two Diplocirrus species included, $D$. longisetosus and D. nicolaji, was not supported.

\section{Discussion}

The present specimens agreed well with the original and subsequent descriptions of Diplocirrus nicolaji in following diagnostic features: 1) notochaetae in anterior
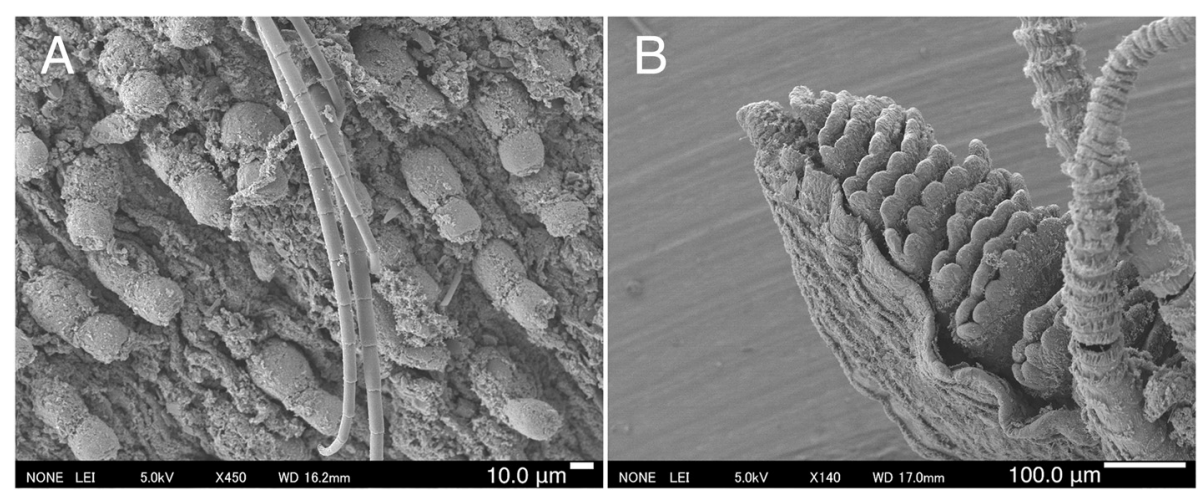

Fig. 2 Scanning electron micrographs of Diplocirrus nicolaji from Misaki (NSMT-Pol-113036): (a) Lateral view of neurochaetae and papillae on the tunic surface in a median chaetiger; (b) frontal view of anterior and posterior branchiae 

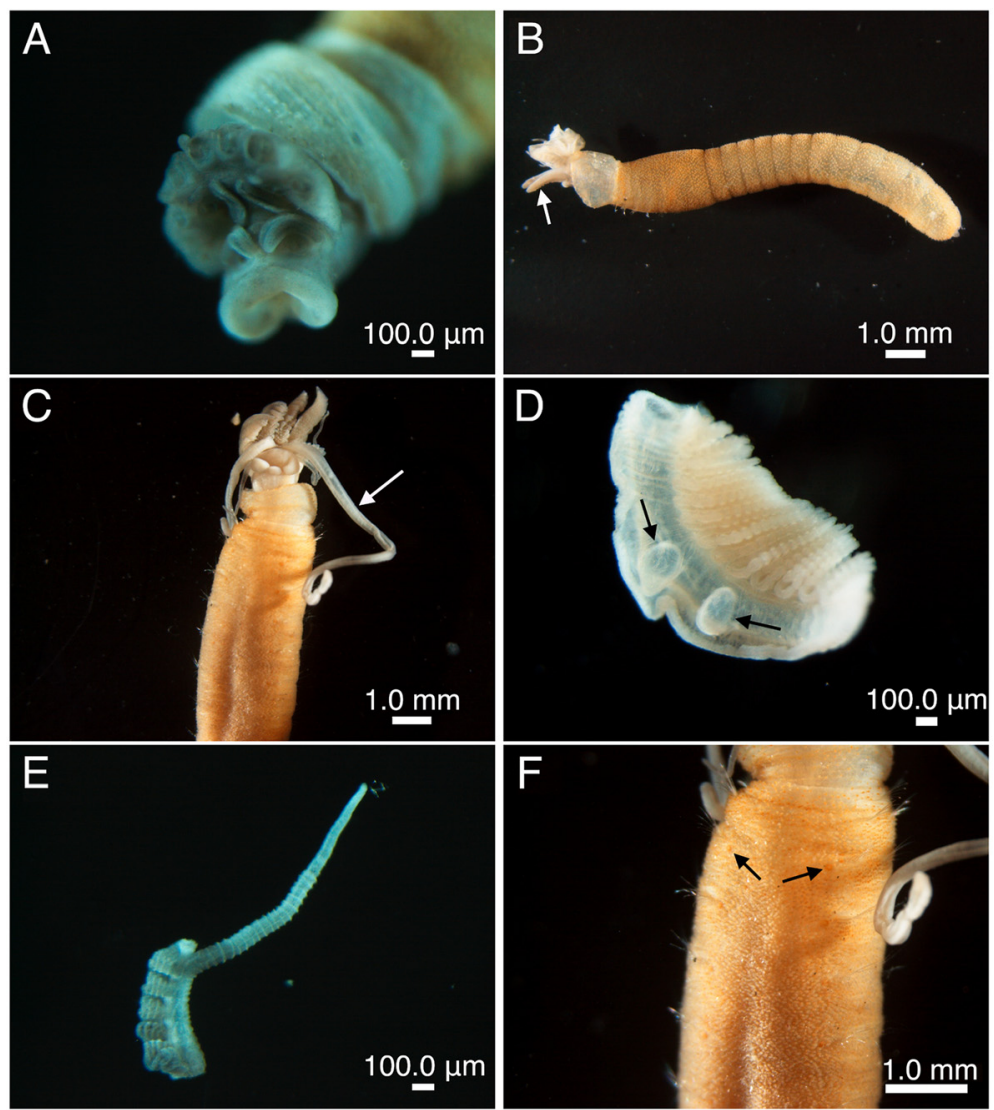

Fig. 3 Stereoscopic micrographs of Diplocirrus nicolaji: (a) Frontal view of a preserved specimen from Misaki (NSMT-Pol-113034) without head appendages for clarity; (b) dorsolateral view of a preserved specimen from Komatsubara (NSMT-Pol-113035) with palps (1.2 mm in length) (arrow); (c) ventral view of a preserved specimen from Oshoro (NSMT-Pol-113032) with palps (8.3 mm in length) (arrow); (d) lateral view of a posterior branchia taken from a specimen from Komatsubara (NSMT-Pol-113035) showing the two sucker-like sockets (arrow); (e) lateral view of an anterior branchia taken from a specimen from Misaki (NSMT-Pol-113034); (f) anteroventral view of a preserved specimen from Oshoro (NSMT-Pol-113032) showing the gonopores in each segment (arrow)

setigers are very short and do not form a cephalic cage; 2) papillae on the tunic are relatively short, digitate or bowling-pin shaped, and arranged in 10-17 rows per segment; 3) ventrolateral gonopores are present from chaetiger 2 ; 4) neurochaetae in median chaetigers are barely tapered with markedly falcate tips; and 5) the lamellate region of the anterior cirriform branchiae extends to one-third of the branchial length (Buzhinskaja 1994; Salazar-Vallejo and Buzhinskaja 2011). They were thus identified as D. nicolaji with little hesitation. Although a few morphological variations were found among the local populations (see above), our phylogenetic analysis confirmed that the present specimens are conspecific with little genetic divergence (Fig. 4). The differences of palp length among each population might be attributable to the various anesthesia durations. Meanwhile, our analysis based only on COXI sequences did not resolve the inter-family relationships of Flabelligeridae as shown in Osborn and Rouse (2011), which might reflect the fact that the COXI is relatively unconserved. More gene sequences from both the nuclear and mitochondrial genomes, as well as increased taxonomic samplings, will be needed for the better resolution.

Imajima (1992) and Uchida (1992) also reported the genus Diplocirrus from Japanese waters; the former recorded Diplocirrus sp. from shallow waters off Sarufutsu, northern Hokkaido, and the latter merely included this genus in his key of shallow-water flabelligerids in Japan. Unfortunately, we could not ascertain their identification nor compare these records with $D$. nicolaji since they gave no specific accounts of their species. Consequently, this is the first report of the detailed description of the morphology and distribution of the genus Diplocirrus, as well as D. nicolaji, from Japan.

In this study, $D$. nicolaji was collected from shallow waters (up to a depth of $10 \mathrm{~m}$ ) along Japanese coasts (Fig. 1). This is the first report of $D$. nicolaji from the Pacific Ocean and extends its distribution southward (Komatsubara, Seto Inland Sea). Therefore the distribution 




Fig. 4 Maximum-likelihood (ML) tree based on mitochondrial COXI sequence. Acrocirrus validus and Macrochaeta clavicornis (Acrocirridae) were used as outgroups. Nodal support values (bootstrap support) higher than $70 \%$ are indicated above the branches

of D. nicolaji is not restricted to northern cold waters in the Sea of Japan. Although intertidal to shallow-water polychaete faunae in central to southern Japan have been relatively well surveyed (e.g., Inaba 1988; Nishi et al. 2001; Nishi and Kudo 2003, 2005; Sato 2000; Yamanishi and Sato 2007; Nishi and Kupriyanova; 2011), D. nicolaji was not recorded in those studies and may thus have been overlooked. Future surveys will add its new distributional records in Japanese waters and the vicinity.

This study contributes to the pool of knowledge on Japanese coastal biodiversity and will help generate more accurate environmental assessments. Furthermore, the given COXI sequences will be helpful for the future accurate identification of this species, that is, DNA barcoding. Recently, a number of cryptic species have been discovered through DNA barcoding analyses, even among polychaetes (see Nygren 2014). We have taken a first step toward unraveling the cryptic diversity of Flabelligeridae occurring in Japanese waters.

\section{Acknowledgements}

We thank Ms. Shinri Tomioka of Hokkaido University; Messrs. Mamoru Sekifuji and Hisanori Kohtsuka of Misaki Marine Biological Station (MMBS) of the University of Tokyo; all participants in the 3rd field workshop UMISAWA held at MMBS; Drs. Masato Kiyomoto, Mamiko Hirose, Gen Hamanaka, and Mr. Mamoru Yamaguchi of the Marine and Coastal Research Center,

Ochanomizu University; Dr. Hiroshi Namikawa of the National Museum of Nature and Science, Tsukuba; Dr. Tadashi Akiyama of Ushimado Marine Laboratory, Okayama University; and Mr. Hayate Tanaka of Tokyo University of Marine Science and Technology for their generous help in collecting specimens. We also thank Mr. Katsuyuki Uematsu of the Japan Agency for Marine-Earth Science and Technology for SEM observations and Dr. Sergio I. Salazar-Vallejo for information on Japanese Diplocirrus. This study was partly supported by a Grant-in-Aid from the Mikimoto Fund for Marine Ecology to $\mathrm{NJ}$ and Japanese Association for Marine Biology (JAMBIO, No. 26-11).

\section{Authors' contributions}

$\mathrm{NJ}$ and MT designed the study, collected the specimens, and drafted the manuscript. NJ conducted the morphological analysis and performed the molecular experiments. MT conducted the phylogenetic analysis. YF helped to improve the manuscript. All authors read and approved the final manuscript.

Competing interests

The authors declare that they have no competing interests. 


\section{Author details}

'Graduate School of Biosphere Science, Hiroshima University, Higashi-Hiroshima 739-8528, Japan. ${ }^{2}$ Department of Marine Biodiversity Research, Japan Agency for Marine-Earth Science and Technology, Yokosuka 237-0061, Japan. ${ }^{3}$ Department of Biology, Faculty of Science, Toho University, Funabashi, Chiba 274-8510, Japan.

Received: 16 March 2016 Accepted: 12 April 2016

\section{Published online: 01 June 2016}

\section{References}

Burnette AB, Struck TH, Halanych KM. Holopelagic Poeobius meseres ("Poeobiidae", Annelida) is derived from benthic flabelligerid worms. Biol Bull. 2005;208:213-20.

Buzhinskaja G. Diversibranchius nicolaji gen. et sp. n. from the Sea of Japan with unique branchial structure (Polychaeta: Flabelligeridae). Zoosyst Rossica. 1994;2:229-31.

Carr CM, Hardy SM, Brown TM, Macdonald TA, Hebert PD. A tri-oceanic perspective: DNA barcoding reveals geographic structure and cryptic diversity in Canadian polychaetes. PLoS One. 2011;6;e22232.

Hardy SM, Carr CM, Hardman M, Steinke D, Corstorphine E, Mah C. Biodiversity and phylogeography of Arctic marine fauna: insights from molecular tools. Mar Biodivers. 2011;41:195-210.

Imajima M. Benthic polychaetes collected by the second cruise of the Japanese expedition of deep seas (JEDS-2). Bull Natl Sci Mus Tokyo. 1964;57:236-53.

Imajima M. Polychaetous annelids around Sarufutsu, northern Hokkaido. Mem Natl Sci Mus Tokyo. 1992;25:125-33.

Imajima M. Polychaetous annelids from Sagami Bay and the Sagami Sea, central Japan. Mem Natl Sci Mus Tokyo. 2006:40:317-408.

Imajima M. Deep-sea benthic polychaetes off Pacific coast of the northern Honshu, Japan. Natl Mus Nat Sci Monogr. 2009;39:39-192.

Imajima M, Hartman O. The polychaetous annelids of Japan, Allan Hancock Occas Pap, no. 26. 1964. p. 452.

Inaba A. Fauna and flora of Seto Inland Sea II, 2nd edition, Mukaishima Marine Biological Station, Hiroshima University. 1988. p. 475

Jirkov I. Polychaeta of the Arctic Ocean. Moskva: Yanus-K; 2001.

Kimura M. A simple method for estimating evolutionary rates of base substitutions through comparative studies of nucleotide sequences. J Mol Evol. 1980;16(2):111-120.

Maddison W, Maddison D. Mesquite: a modular system for evolutionary analysis. Version 2.75. 2011. Available at http://mesquiteproject.org/ Accessed 26 Apr 2015.

Miura T. Record of a deep-sea pelagic annelida, Buskiella vitjasi (Buzhinskaya[sic], 1977) collected off Miyako, northern Japan. Taxa Proc Japanese Soc Syst Zool. 2014;37:31-5.

Nishi E, Kato T, Ueshima R. Polychaetous annelids from off Shimoda Port, Sagami Bay, Japan. Mem Natl Sci Mus Tokyo. 2001;37:251-9.

Nishi E, Kudo T. Fauna of polychaetous annelids in Odawa Bay, central Japan. Bull Kanagawa Pref Fish Res Inst. 2003;8:57-69.

Nishi E, Kudo T. Fauna of polychaetous annelids in Odawa Bay, central Japan. II. Results of 2000. Bull Kanagawa Pref Fish Res Inst. 2005;10:33-43.

Nishi E, Kupriyanova K. Polychaete fauna of Boso Peninsula coasts, with an appendix on polychaete type specimens deposited in Chiba Prefectural Museums. J Nat Hist Mus Inst Chiba Special Issue. 2011;9:45-60.

Nygren A. Cryptic polychaete diversity: a review. Zool Scr. 2014;43:172-83.

Osborn KJ, Rouse GW. Multiple origins of pelagicism within Flabelligeridae (Annelida). Mol Phylogenet Evol. 2008;49:386-92.

Osborn KJ, Rouse GW. Phylogenetics of Acrocirridae and Flabelligeridae (Cirratuliformia, Annelida). Zool Scr. 2011;40:204-19.

Osborn KJ, Haddock SHD, Pleijel F, Madin LP, Rouse GW. Deep-sea, swimming worms with luminescent "Bombs." Science. 2009:325:964.

Rouse GW, Pleijel F. Polychaetes. Oxford: Oxford University Press; 2001.

Salazar-Vallejo SI. Revision of Stylarioides delle Chiaje, 1831 (Annelida: Flabelligeridae). Ital J Zool. 2011a;78(S1):163-200.

Salazar-Vallejo SI. Revision of Piromis Kinberg, 1867 and Pycnoderma Grube, 1877 (Polychaeta: Flabelligeridae). Zootaxa. 2011b;2819:1-50.

Salazar-Vallejo SI. Revision of Semiodera Chamberlin, 1919 (Polychaeta: Flabelligeridae). Zootaxa. 2012;3562:1-62.

Salazar-Vallejo SI. Revision of Pherusa Oken, 1807 (Polychaeta: Flabelligeridae). Zootaxa. 2014:3886:1-61.

Salazar-Vallejo SI, Buzhinskaja G. Revision of Diplocirrus Haase, 1915, including Bradiella Rullier, 1965, and Diversibranchius Buzhinskaja, 1993 (Polychaeta, Flabelligeridae). ZooKeys. 2011;106:1-45.
Salazar-Vallejo SI, Carrera-Parra L, Fauchald K. Phylogenetic affinities of the Flabelligeridae (Annelida, Polychaeta). J Zool Syst Evol Res. 2008;46:203-15.

Sato M. Polychaetes. In: Sato M, editor. Life in Ariake Sea: biodiversity in tidal flats and estuaries. Tokyo: Kaiyu-sha; 2000. p. 184-205.

Silvestro D, Michalak I. raxmIGUI: a graphical front-end for RAxML. Org Divers Evol. 2012;12:335-7.

Stamatakis A. RAxML-VI-HPC: maximum likelihood-based phylogenetic analyses with thousands of taxa and mixed models. Bioinformatics. 2006;22:2688-90.

Tamura K, Stecher G, Peterson D, Filipski A, Kumar S. MEGA6: molecular evolutionary genetics analysis version 6.0. Mol Biol Evol. 2013;30:2725-9.

Tavaré S. Some probabilistic and statistical problems in the analysis of DNA sequences. Lectures Math Life Sci. 1986;17:57-86.

Uchida H. Annelida, Polychaeta. In: Nishimura S, editor. Guide to seashore animals of Japan with color pictures and keys. Osaka: Hoikusha; 1992. p. 310-73.

Yamanishi R, Sato M. Annelida, Polychaeta. In: lijima A, editor. The 7th National Survay on the Natural Environment: Shallow Sea Survay (Tidal Flats). Fujiyoshida: Ministry of the Environment; 2007. p. 183-93.

Yang Z. Maximum-likelihood estimation of phylogeny from DNA sequences when substitution rates differ over sites. Mol Biol Evol. 1993:10:1396-401.

\section{Submit your next manuscript to BioMed Central and we will help you at every step:}

- We accept pre-submission inquiries

- Our selector tool helps you to find the most relevant journal

- We provide round the clock customer support

- Convenient online submission

- Thorough peer review

- Inclusion in PubMed and all major indexing services

- Maximum visibility for your research

Submit your manuscript at www.biomedcentral.com/submit
) Biomed Central 